\title{
Hinokitiol Production in Suspension Cells of Thujopsis dolabrata var. hondai Makino
}

\author{
Ryo FujiI, Kazuo Ozaki, Migifumi Ino and Hitoshi Watanabe \\ Integrated Technology Laboratories, Takeda Chemical Industries, Ltd. \\ 11, Ichijoji-takenouchi-cho, Sakyo-ku, Kyoto 606 Japan
}

(Received May 19, 1994)

(Accepted October 8, 1994)

\begin{abstract}
Suspension cells of Thujopsis dolabrata var. hondai Makino were used as the material for studying the culture conditions by a two-step culture method (cell growth step and secondary metabolite production step) for the production of hinokitiol ( $\beta$-thujaplicin). Murashige and Skoog's(MS) medium containing $\mathrm{NO}_{3}-\mathrm{N}$ and $\mathrm{NH}_{4}-\mathrm{N}$ in the ratio $3 \sim 5: 1$ (total nitrogen $30 \sim 75 \mathrm{mM}$ ) with $1.0 \mathrm{mg} / l \mathrm{NAA}$ and $0.2 \mathrm{mg} / l \mathrm{TDZ}$ was most desirable for cell growth (MS-O medium). The growth showed 14-fold increase after 30 days of culture in this medium. A higher ratio of $\mathrm{NH}_{4}-\mathrm{N}$ to total nitrogen resulted in hinokitiol accumulation in the cells. When the cells were transferred to the modified MS-O medium with the ratio of $\mathrm{NO}_{3}-\mathrm{N}: \mathrm{NH}_{4}-\mathrm{N}$ changed to $1: 2$ (MS-PC medium), an increase of hinokitiol level was observed. Also feeding acetates to the medium enhanced hinokitiol accumulation considerably. The highest hinokitiol content of $422 \mu \mathrm{g} / \mathrm{g} \mathrm{FW}$ was obtained when the cells were cultured in MS-O medium supplemented with $4.3 \mathrm{mM}$ acetic acid.
\end{abstract}

\section{Introduction}

An irregular monoterpene hinokitiol ( $\beta$-thujaplicin) is widely present in the heartwood of the families Cupressaceae ${ }^{1)}$. Hinokitiol has antimicrobial properties, and recently it has been indicated that hinokitiol suppresses ethylene synthesis and respiration of some fruits and vegetables. For this reason, hinokitiol is used for preserving foods, and the demand for hinokitiol is now increasing ${ }^{2}$.

Witte $e t ~ a l .{ }^{3)}$ found various monoterpens including hinokitiol and diterpens in suspension culture of Thuja occidentalis. They also pointed out that hinokitiol was detected mainly in the cell extract, but the cell growth was poor and the yield of hinokitiol was rather low ${ }^{4}$. Still the understanding of the biosynthetic pathway of hinokitiol remains rudimentary ${ }^{5,6}$.

In Japan, Thujopsis dolabrata is the most common source for hinokitiol extraction, although, the heartwood contains hinokitiol no more than $0.06 \%$ of dry weight ${ }^{7}$. We therefore attempted to produce hinokitiol by means of suspension culture. Improving cell growth and synthesis of secondary metabolites is necessary to obtain a high yield of metabolites. The objective of the present study is to apply the two-step culture method $^{8)}$ for the production of hinokitiol in suspension cells of Thujopsis dolabrata. We also report that the addition of acetates is an effective means of hinokitiol accumulation.

\section{Materials and Methods}

\section{Suspension cells and culture method}

Suspension cells (cell line 92-910H) were derived from hypocotyl of Thujopsis dolabrata var. 
hondai Makino, which were maintained at $25^{\circ} \mathrm{C}$ in the dark on a rotary shaker $(80 \mathrm{rpm})$ in MS liquid medium ${ }^{9}$ containing $1.0 \mathrm{mg} / l$ naphthaleneacetic acid(NAA) and $30 \mathrm{~g} / l$ sucrose (MS- $1 \mathrm{~N}$ medium) which was changed every 2 weeks. Cells $(c a .0 .5 \mathrm{~g})$ were transferred to plastic petri-dishes $(\phi 9$ $\mathrm{cm}$ ) containing $20 \mathrm{~m} l$ of liquid medium.

\section{Nitrogen nutrition}

The ratio of $\mathrm{NO}_{3}-\mathrm{N}$ to $\mathrm{NH}_{4}-\mathrm{N}$ was controlled by the amount of $\mathrm{KNO}_{3}$ and $\mathrm{NH}_{4} \mathrm{Cl}$, respectively.

\section{Plant hormones}

Auxins (NAA, 2, 4-dichlorophenoxyacetic acid, picloram, 3-indoleacetic acid and 3-indolebutyric acid) and cytokinins (2-isopentenyladenine, kinetin, 6-benzylaminopurine, zeatin and thidiazuron (TDZ)) were used for the study of cell growth.

\section{Addition of acetates}

Acetic acid, potassium acetate, sodium acetate, ammonium acetate and magnesium acetate were added to MS- $1 \mathrm{~N}$ medium, respectively and $\mathrm{pH}$ was adjusted to 5.8 with $\mathrm{NaOH}$ or $\mathrm{HCl}$ before autoclaving.

\section{Extraction and HPLC conditions}

Fresh cells were extracted with $1 \%(\mathrm{v} / \mathrm{v})$ methanolic $\mathrm{HCl}$ in an ultrasonic bath. The extract was analyzed by HPLC on Wakosil-II $5 \mathrm{c} 18 \mathrm{HG}$ column $(4.6 \times 250 \mathrm{~mm}$, Wako pure chemical) with $60 \%$ $(\mathrm{v} / \mathrm{v}) \mathrm{MeOH}$ containing $0.1 \%(\mathrm{v} / \mathrm{v}) \mathrm{H}_{3} \mathrm{PO}_{4}$ and $0.025 \%(\mathrm{w} / \mathrm{v}) \mathrm{Na}_{2}$ EDTA as eluent with a flow rate of $1.0 \mathrm{ml} / \mathrm{min}$. The detection was carried out at $254 \mathrm{~nm}$.

\section{Identification of hinokitiol}

The gas chromatograph coupled with a mass spectrometer(Jeol JMS-DX303HF) was used. Spectra were recorded at an electron energy of $20 \mathrm{eV}$.

\section{Results and Discussion}

\section{Cell growth step}

Owing to the fact that the suspension cells cultured in MS-1N medium grew about 7 times at most after 30 days of culture, the effects of nitrogen nutrition and plant hormones on cell growth were investigated. It has been shown that the ratio of $\mathrm{NO}_{3}-\mathrm{N}$ to $\mathrm{NH}_{4}-\mathrm{N}$ and plant hormones play an important role in the growth of suspension cells ${ }^{10,11)}$. The cell growth of Thujopsis dolabrata was

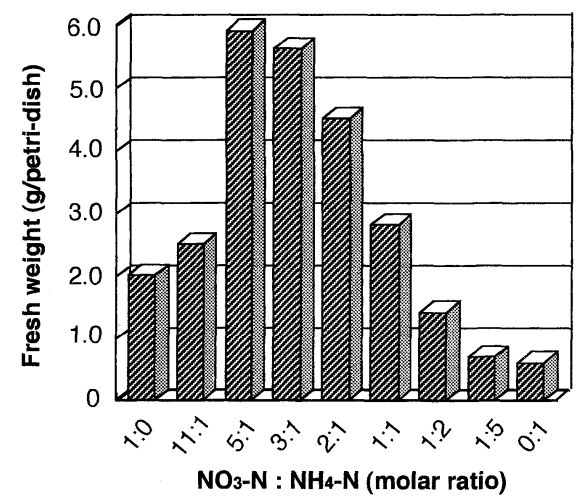

Fig. 1 Effect of the ratio of $\mathrm{NO}_{3}-\mathrm{N}$ to $\mathrm{NH}_{4}-\mathrm{N}$ on growth of $T$. dolabrata var. hondai suspension cells after 30 days of culture.

MS- $1 \mathrm{~N}(1 \mathrm{mg} / l \mathrm{NAA}$ and $30 \mathrm{~g} / l$ sucrose $)$ with the varied ratio of $\mathrm{NO}_{3}-\mathrm{N}$ to $\mathrm{NH}_{4}-\mathrm{N}$. $\mathrm{KNO}_{3}$ and $\mathrm{NH}_{4} \mathrm{Cl}$ were used as sources of nitrate and ammonium respectively, without changing total nitrogen concentration at $60 \mathrm{mM}$. The cells were transferred once to fresh medium during the treatment. 


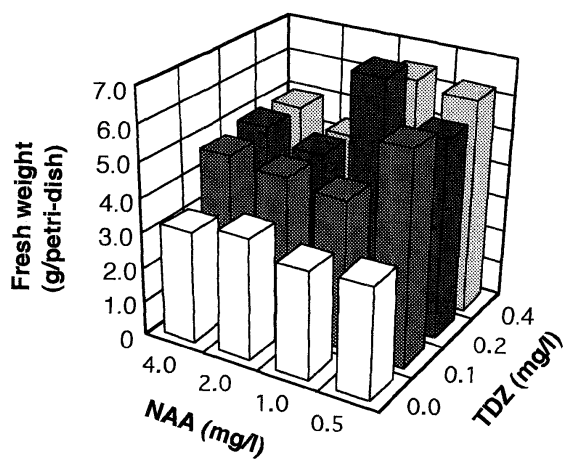

Fig. 2 Effect of the combination of NAA and TDZ on growth of T. dolabrata var. hondai suspension cells after 30 days of culture.

affected by the ratio of $\mathrm{NO}_{3}-\mathrm{N}$ to $\mathrm{NH}_{4}-\mathrm{N}$. The maximum fresh weight was found in the ratio between $5: 1$ and $3: 1$, leading to the conclusion that the ratio of $3 \sim 5: 1$ is desirable for growth of suspension cells (Fig. 1). This $\mathrm{NO}_{3}-\mathrm{N}$ ratio was lower than that of Gamborg-B5(B5)medium $(12.5: 1)$, and higher than that of MS basal medium $(2: 1)$. The concentration of total nitrogen was then changed keeping the ratio of $\mathrm{NO}_{3}-\mathrm{N}$ to $\mathrm{NH}_{4}-\mathrm{N}$ to $4: 1$, cell growth remained stable with $30 \sim 75 \mathrm{mM}$ (data not shown).

In the preliminary experiments, addition of NAA as auxin or TDZ as cytokinin to MS basal medium showed successful cell growth. Huetteman and Preece ${ }^{12)}$ showed that exposure to TDZ enhanced in vitro establishment and the proliferation of woody plants. The combination effect of NAA and TDZ were then examined (Fig. 2). The cells cultured in MS basal medium supplemented with $1.0 \mathrm{mg} / l \mathrm{NAA}$ and $0.2 \mathrm{mg} / l \mathrm{TDZ}$ showed the highest growth rate(14 times).

Based on these results, MS medium containing $\mathrm{NO}_{3}-\mathrm{N}$ and $\mathrm{NH}_{4}-\mathrm{N}$ in the ratio $4: 1$ of total nitrogen at $30 \mathrm{mM}$ with $1.0 \mathrm{mg} / l \mathrm{NAA}, 0.2 \mathrm{mg} / l \mathrm{TDZ}$ and $30 \mathrm{~g} / l$ sucrose was adopted as a basal growth medium (MS-O).

\section{Hinokitiol production step}

The HPLC peak was identified by means of GC-MS as hinokitiol (data not shown).

There are some studies that secondary metabolite production was affected by the form of nitrogen source used in the medium ${ }^{13-15}$. Hinokitiol production was examined by varying the ratio of $\mathrm{NO}_{3}-\mathrm{N}$ and $\mathrm{NH}_{4}-\mathrm{N}$. Culture in modified MS-1N medium did not enhance hinokitiol content (less than $12.1 \mu \mathrm{g} / \mathrm{g} \mathrm{FW}$ ). On the other hand, hinokitiol production was stimulated when the cells were cultured in modified MS-O medium of which more than half of total nitrogen was supplied as $\mathrm{NH}_{4}-\mathrm{N}$ (Fig. 3).

Consequently, modified MS-O medium with the ratio of $\mathrm{NO}_{3}-\mathrm{N}: \mathrm{NH}_{4}-\mathrm{N}$ changed to $1: 2$ was the most suitable for hinokitiol production(MS-PC medium).

The time courses of hinokitiol accumulation and cell growth in four kinds of media were then examined (Fig. 4). Hinokitiol content was high when the medium was not suitable for cell growth. In MS-PC medium, hinokitiol content of the cells was increased substantially during the first 14 days in spite of low growth, reaching a peak of $227 \mu \mathrm{g} / \mathrm{g} \mathrm{FW}$ followed by a gradual decrease.

In the hinokitiol production step, the suspension cells that showed vigorous hinokitiol accumulation doubled at most after 30 days of culture. Such an inverse relationship between growth and secondary metabolite production has been reported in other plant cell cultures ${ }^{16,17)}$.

The growth rate doubled when the suspension cells were cultured in MS-O medium. When these cells were then transferred to the medium for production(MS-PC medium), hinokitiol accumulation 


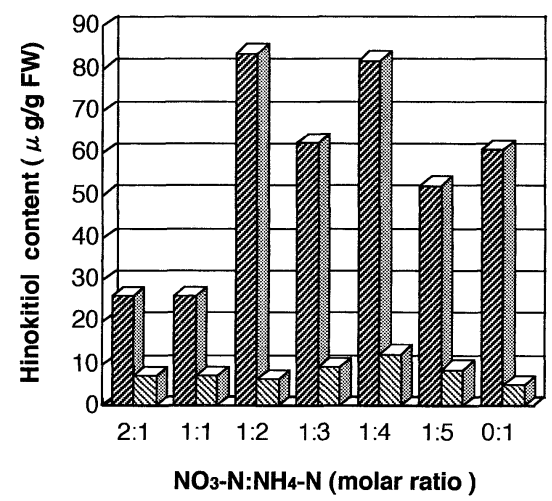

Fig. 3 Effect of the ratio of $\mathrm{NO}_{3}-\mathrm{N}$ to $\mathrm{NH}_{4}-\mathrm{N}$ on hinokitiol accumulation in suspension cells of $T$. dolabrata var hondai after 7 days of treatment.

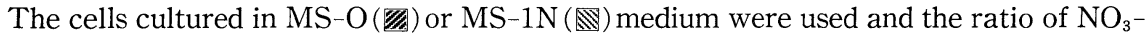
$\mathrm{N}$ to $\mathrm{NH}_{4}-\mathrm{N}$ of the medium was changed. $\mathrm{KNO}_{3}$ and $\mathrm{NH}_{4} \mathrm{Cl}$ were used as sources of nitrate and ammonium without changing total nitrogen concentration at $60 \mathrm{mM}$ (MS$1 \mathrm{~N})$ and $30 \mathrm{mM}(\mathrm{MS}-\mathrm{O})$. MS-O medium: $1 \mathrm{mg} / l \mathrm{NAA}, 0.2 \mathrm{mg} / l \mathrm{TDZ}, \mathrm{NO}_{3}-\mathrm{N}: \mathrm{NH}_{4}{ }^{-}$ $\mathrm{N}=4: 1$

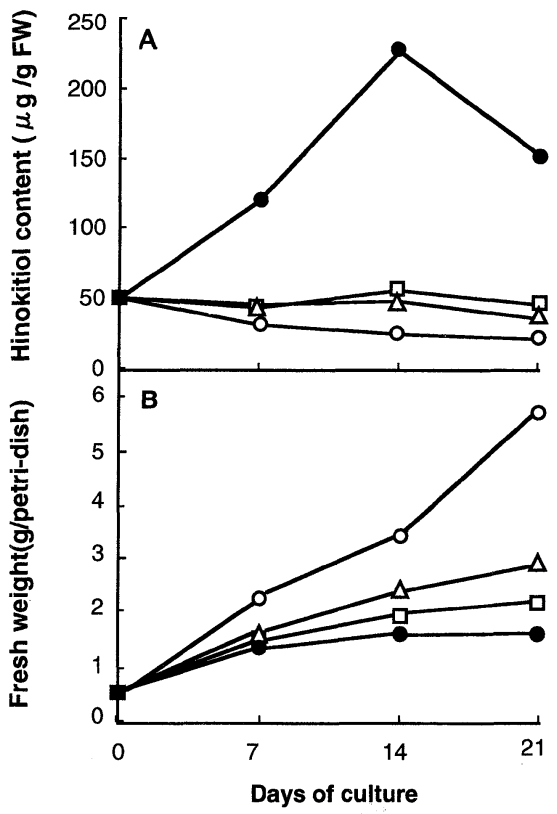

Fig. 4 Time course of hinokitiol accumulation(A) and growth(B) of T. dolabrata var. hondai suspension cells cultured in various media.

The cell cultured in MS-O were used. $\triangle$, MS- $1 \mathrm{~N}$; $\square$, B5 (with $0.5 \mathrm{mg} / l \mathrm{NAA}$ ); $\bigcirc$, MS$\mathrm{O}\left(\mathrm{NO}_{3}-\mathrm{N}: \mathrm{NH}_{4}-\mathrm{N}=4: 1,1 \mathrm{mg} / l \mathrm{NAA}, 0.2 \mathrm{mg} / l\right.$ TDZ $) ;$ $\mathrm{N}=1: 2,1 \mathrm{mg} / l \mathrm{NAA}, 0.2 \mathrm{mg} / l \mathrm{TDZ}$ )

was found to increase considerably in 14 days of culture. In this way we established the two-step culture method.

\section{Feeding of acetates}

The increase of hinokitiol content in cells was observed when acetic acid was added to liquid medium. The results suggested that acetic acid was the basic precursor for the synthesis of hinokitiol via acetate-mevalonate pathway. A few experiments were conducted to clarify the acetic acid effect on hinokitiol production. Hinokitiol contents were proportional to the change of acetic acid concentration less than $8.6 \mathrm{mM}$, and addition of acetic acid at $4.3 \mathrm{mM}$ gave the 


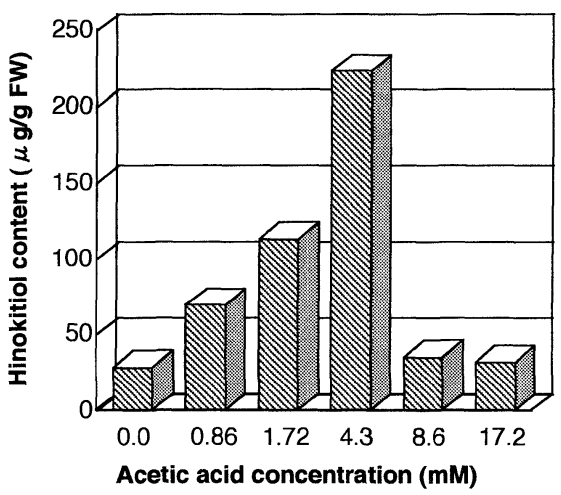

Fig. 5 Effect of various concentrations of acetic acid feeding to MS-1N medium on hinokitiol accumulation in suspension cells of $T$. dolabrata var. hondai.

The cells cultured in MS-O medium were used. The cells were harvested after 9 days of treatment.

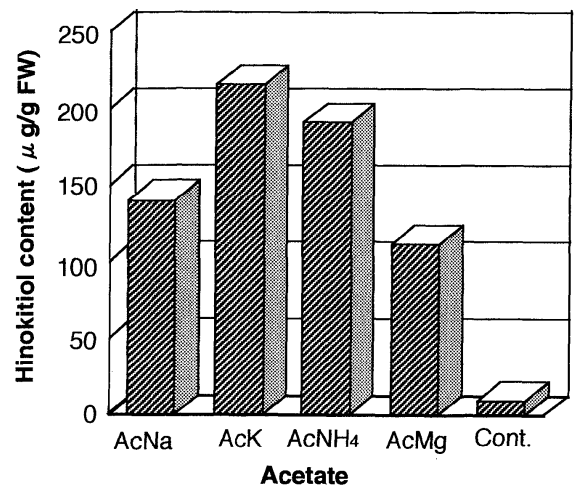

Fig. 6 Effect of the addition of various acetates at $4.3 \mathrm{mM}$ on hinokitiol accumulation in suspension cells of $T$. dolabrata var. hondai.

The cells cultured in MS-O medium were used. The cells were harvested after 9 days of culture.

maximum content of $223 \mu \mathrm{g} / \mathrm{g} \mathrm{FW}$ (Fig. 5). Acetic acid addition showed marked reduction of cell growth, however (data not shown). The addition of four other kinds of acetates also increased the hinokitiol content of the cells (Fig. 6). Added form of acetates caused differences in the final culture pHs from 4.0 to 5.4 , while the cells cultured in the medium with added acetic acid and with an unadjusted $\mathrm{pH}(3.7)$ did not accumulate hinokitiol(data not shown). The variations in hinokitiol content probably depends on the change in the medium $\mathrm{pH}$. Also the kind of medium markedly effected the hinokitiol accumlation. The suspension cells cultured in MS-1N, MS-O and MS-PC media were transferred to the respective medium supplemented with acetic acid at $4.3 \mathrm{mM}$. Noticing, however, that the cells could not be maintained in MS-PC medium, part of the cells cultured in MS-O medium was transferred to MS-PC medium seven days before the addition of acetic acid. The highest hinokitiol content of $422 \mu \mathrm{g} / \mathrm{g} \mathrm{FW}$ was obtained when cells cultured in MS$\mathrm{O}$ medium were transferred to MS-O medium supplemented with acetic acid. On the other hand, the cells cultured in MS-PC medium did not respond to acetic acid addition(Fig. 7). Transfer of suspension cells to MS-PC medium repressed cell growth with a gradual change of cell color from yellowish white to brown. It was hence inferred that the ability of the cells to absorb or translocate added acetic acid was reduced, and as a result, the cells cultured in MS-PC medium accumulated only a small amount of hinokitiol. Consequently, feeding acetates was an effective 


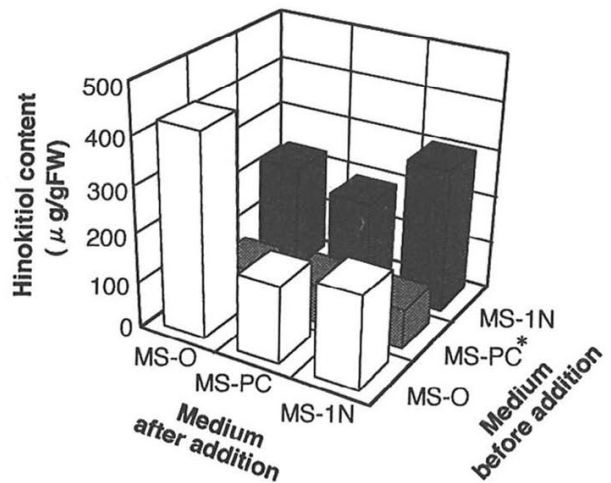

Fig. 7 Effect of media on hinokitiol accumulation in suspension cells of $T$. dolabrata var. hondai.

Acetic acid was added to the media at $4.3 \mathrm{mM}$.

The cells cultured in MS-1N or MS-O medium were used. The cells were harvested after 7 days of addition. *Part of cells cultured in MS-O medium were transferred to MS-PC medium for 7 days before addition.

means for hinokitiol formation. Further work with ${ }^{14} \mathrm{C}$ tracers is necessary to determine hinokitiol biosynthesis from acetic acid.

The addition of weak alkaline acetate such as potassium acetate can adjust the medium $\mathrm{pH}$ which tends to decrease during the culture. In practice, this method is convenient because it does not require the transfer of cells from growth medium to production medium, making it useful in the commercial hinokitiol production.

We found that the suspension cells induced from other species of Cupressaceae family produced hinokitiol and grew faster than the cell line used in this study. It is expected that further selection of cells will contribute to the development of more efficient hinokitiol production methods.

\section{Acknowledgment}

We thank Dr. Y. Hayashi, Forestry \& Forest Products Research Institute for his valuable suggestions on chemical analysis.

\section{References}

1) Gardner, J. A. F., 1962. In "Wood extractives and their significance to the pulp and paper industry" (ed. by Hillis, W. E.), p. 317-330, Academic press, New York and London.

2) Ohkubo, M., 1990. Shokuhin to Kaihatsu (JPN), 24: 39-46.

3) Witte, L., J. Berlin, V. Wray, W. Schubert, W. Kohl, G. Hoefle, J. Hammer, 1983. Planta Med., 49: 216-221.

4) Berlin, J., L. Witte, 1988. Phytochemistry, 27: 127-132.

5) Manitto, P., 1981. In "Biosynthesis of natural products", p. 235, John Willey \& Sons Ltd.

6) Sakai, K., K. Kusaba, Y. Tsutsumi, T. Shiraishi, 1994. Mokuzai Gakkaishi (JPN), 40: 1-5.

7) Okabe, T., K. Saito, Y. Otomo, 1989. Fragrance J., 17: 74-79.

8) Sahai, O. P., M. L. Shuler, 1984. Biotechnol. Bioeng., 26: 27-36.

9) Murashige, T., F. Skoog, 1962. Physiol. Plant., 15: 473-479.

10) De-Eknamkul. W., B. E. Ellis, 1984. Planta Med., 50: 346-350.

11) Dougall, D. K., 1980. In "Plant tissue culture as a source of biochemicals" (ed. by Staba, E. J.), p. 21-58, CRC Press, Boca Raton, Florida.

12) Huetteman, C. A., J. E. Preece, 1993. Plant Cell Tiss. Org. Cult., 33: 105-119.

13) Fujita, Y., Y. Hara, J. Ogino, C. Suga, 1981. Plant Cell Rep., 1: 59-60. 
14) Fukui, H., K. Yazaki, M. Tabata, 1984. Phytochemistry, 23: 2398-2399.

15) Furuya, T., T. Yoshikawa, Y. Orihara, H. Oda, 1984. J. Natur. Prod., 47: 70-75.

16) Neumann, D., G. Krauss, M. Hieke, D. Groger, 1983. Planta Med., 48: 20-23.

17) Yamada, Y., Y. Fujita, 1986. In “Handbook of plant cell culture Vol. 1” (eds. by Evans, D. A., W. R. Sharp, P. V. Ammirato, Y. Yamada), p. 717-728., Macmillan Publishing Company, New York.

\title{
《和文要約》
}

ヒノキアスナロ(Thujopsis dolabrata var. hondai Makino)の細胞培養によるヒノキチオールの生産

\author{
藤井 亮・尾崎和男・井野右文・渡辺 斉
}

\section{武田薬品工業株式会社 応用技術研究所}

細胞培養によるヒノキチオールの生産を目的にヒノキアスナロ(Thujopsis dolabrata var. hondai Makino）の奬濁培養細胞を用いて，二段階培養（細胞増殖段階および物質生産段階）における培地条件につい て検討した。 細胞の増殖には, $\mathrm{NO}_{3}-\mathrm{N}: \mathrm{NH}_{4}-\mathrm{N}$ をモル比で 3〜 5: 1, 無機態窒素の総量を 30〜 $75 \mathrm{mM} に$ 修正し, $1.0 \mathrm{mg} / l \mathrm{NAA}, 0.2 \mathrm{mg} / l \mathrm{TDZ}$ を添加したMurashige and Skoog (MS)培地が最も適しており (MS-O 培地), 培養 30 日後に約 14 倍に増殖した. ヒノキチオールの細胞内への蓄積は, $\mathrm{MS}$ 培地の $\mathrm{NH}_{4}-$ $\mathrm{N}$ 比を高めると増加し, $\mathrm{NO}_{3}-\mathrm{N}: \mathrm{NH}_{4}-\mathrm{N}$ を $1: 2$ に修正した MS-O 培地(生産培地, MS-PC 培地)におい て高い値を示した。ささらに酢酸あるいは酢酸塩の液体培地への添加によってヒノキチオール生産量が大幅に 増加することを見い出した. MS-O 培地に酢酸を $4.3 \mathrm{mM}$ 添加した場合にヒノキチオールは最高值で $422 \mu$ $\mathrm{g} / \mathrm{g} F W$ 細胞内に蓄積された。 